\title{
THE OCCURRENCE AND ORIGIN OF ANALCITE AND MEERSCHAUM BEDS IN THE GREEN RIVER FORMATTON OF UTAH, COLORADO, AND WYOMING
}

\author{
By Wilmot H. BradLex
}

\begin{abstract}
Thin beds that consist almost wholly of euhedral analcite crystals occur at five or more horizons in the upper half of the Green River formation of Utah and Colorado, a series of Eocene lake beds that contain large deposits of oil shale. Most of these beds contain also minute crystals of apophyllite. The analcite crystals in some beds are cemented only by chalcedony, but in other beds that have less analcite the matrix is tuffaceous and consists of chalcedony in which are embedded splinters of feldspar, horublende, and quartz, laths of biotite, and euhedral crystals of sanidinc, apatitc, and zircon. Analcite occurs plentifully also, disseminated in many of the oil-shale beds, and locally makes up as much as $\mathbf{1 6}$ per cent of weight of the rock. In these beds the analcite is accompanied by apophyllite, euhedral crystals of sanidine and orthoclase, angular fragments of quartz, and a little volcanic glass. The rocks associated with the beds of analcite and analcite-bearing oil shale contain salt-crystal cavitics, that strongly suggest the former presence of glauberite and anhydrite.

Both clastic and hydrothermal hypotheses for the origin of the \%colites are considered and dismissed in the paper. The field and microscopic evidence presented leads to the conclusion that all the analcitc and apophyllite formed.in place on the lake bottom as a result of interactions between salts dissolved in the lake water and the dissolution products of volcanic ash that fell into the lake.

Mecrschaum, or fibrous scpiolite, occurs in several thin beds near the top of the Green River formation in Duchesne County, Utah. It is mixed with structureless organic matter like that in the oil shale and apparently formed in place on the lake bottom.

Chemical analyses of the analcite rock and of the sepiolite are given.
\end{abstract}

\section{INTRODUCTION}

SCOPE AND PURPOSE OF THE REPORT

Analcite is rare in sedimentary rocks, but its occurrence as extensive beds is even more remarkable. In an earlier paper ${ }^{1}$ the occurrence of thin beds of euhedral analcite crystals was noted briefly, and the hypothesis was advanced that they were derived from volcanic ash. These beds are so unusual as to merit more than incidental record. They represent a new phase in the alteration of volcanic ash, and as end products of that alteration they may perhaps be regarded as genetic relatives of bentonite, though their mineralogic composition and physical properties are utterly diflerent. They indicate that analcite and apophyllite, which also occurs in these beds, can form at normal temperatures of the earth's surface and

1 Bradley, W. M., Zeolito beds in the Green River formation: Science, new ser., vol. $07, \mathrm{pp}, 73-74,1028$. without the agency of gaseous or liquid emanations from lavas or volcanic sources; consequently, they provide a basis for supposing that definitely crystallized zeolites may be expected in either fossil or recent alkali soils. The analcite beds may have economic value as a source of zeolitic material for water softening. Finally, because of their remarkable areal extent they serve as useful correlative units within the part of the Green River formation that contains the richest beds of oil shale.

Therefore, the writer's purpose in this report is to describe the deposits of analcite in the Green River formation, to compare them with other similar deposits, and to present the observations and inferences that led him to explain them as alteration products of volcanic ash that fell into an ancient saline lake. The report also records the occurrence of several thin beds of sepiolite, or meerschaum, in the Green River formation and presents new data on the molds of saline minerals of the Green River formation whose determination affects directly the interpretation of the analcite and sepiolite deposits.

\section{FIELD WORK AND ACKNOWLEDGMENTS}

The observations and results recorded here are, in a way, by-products of the writer's study of the Green River formation, which began in 1922 and is still in progress. The specimens of analcite rock described were collected during the field season of 1925 , when the writer was assisted by R. D. Ohrenschall. Some of the thin sections, however, which showed most clearly the tuffaceous matrix of the analcite beds were cut from specimens collected by $\mathrm{D}$. E. Winchester in 1914. These sections were recorded with the obviously tentative field name sandstone.

\section{OCCURRENCE OF ANALCITE IN OTHER SEDIMENTARY DEPOSITS}

In clays of middle Cretaceous age near Duingen, Germany, Von Seebach ${ }^{2}$ found clay ironstone concretions incrusted with dolomite and trapezohedrons of analcite. The crystals were colorless or whitish. Although apparently not genetically related to volcanic ash the deposit seems to have originated under conditions of low temperature, for Von Seebach remarks

\footnotetext{
2 Von Seebach, Karl, Notiz über ein neues Vorkommen des Analcim: Georg
} Augusts Univ. K. Gesell. Wiss. Göttingen Nachr., 1862, pp. 334-335. 
that it is similar to the deposits of carbonates and quartz known to occur only in nonvolcanic regions. Guthe ${ }^{3}$.confirmed Von Seebach's identification of the analcite by an analysis, which showed some ferric iron and an excess of water. These apparent impurities may, however, have been due to the traces of a reddish incrustation on the crystals noted by Guthe.

Another occurrence of analcite in sedimentary beds near Lehre, Germany, is recorded by Kloos. ${ }^{4}$ This deposit also appears to have formed at a low temperature, despite the intergrowth of the analcite with sphalerite.

The formation of the analcite was clearly subsequent to the diagenesis of the beds in both the deposit described by Von Seebach and that described by Kloos. Neither is therefore strictly comparable to the syngenetic deposits of analcite and apophyllite in the Green River formation.

More nearly analogous to the zeolites of the Green River formation in its mode of occurrence is the zeolite phillipsite which Murray and Renard ${ }^{5}$ found to be forming in large quantities in the red deep-sea oozes. In those oozes they found an exceptional abundance of fragmental lapilli of vesicular basalt, much of which had a glassy groundmass, also palagonite, a hydration product of basaltic glass. They regarded the phillipsite as produced from volcanic material by a process of hydration and alteration that went on very slowly because of the low temperature, $2^{\circ}-3^{\circ} \mathrm{C}$., and the almost total quiescence of the water.

A palagonite tuff from a small island 3 miles eastnortheast of Reykjavik, Iceland, which has been partly altered to analcite, faujasite, and an impure potash analogue of analcite, has been described by Tyrrell and Peacock. ${ }^{6}$ This tuff consists largely of clear yellow perfectly isotropic palagonite, which they characterize as gel-like. Of the significance of this variety of palagonite they say:

It was previously indicated that gel-palagonite appears to have a somewhat higher water content than fibro-palagonite, and on considering the notes on the occurrence of the various specimens we find that the tuffs which are characterized by gel-palagonite are those which have been submerged and have, therefore, been acted on at raised pressure (hydrostatic) and low temperature, while those which contained dominant fibropalagonite were always associated with hot springs. ${ }^{7}$

The analcite of the deposit is evidently very closely similar in its mode of occurrence to the analcite in the water-laid tuffs of the Green River formation.

Beds of analcite that formed in playas in western Yavapai County, Ariz., have been described recently

${ }^{3}$ Guthe, H., Mineralogische Notiz: Naturhist. 'Gesell. Hannover 12. Jahresb., p. $41,1863$.

4 Kloos, J. H., Über Analcim auf Steinkernen von Ammoniten und auf Sphärosiderit von Lehre: Ver. Naturwiss. Braunschweig 11. Jahresb., pp. 153, 167-168, 1899.

5 Murray, John, and Renard, A. F., Challenger Rept., Deep-sea deposits, pp. 400-411, 1891.

OTyrrell, G. W., and Peacock, M. A., The petrology of Iceland: Roy. Soc. Edinburgh Trans., vol. 55 , pt. 1 , No. 3, pp. 62-63, 1926.

7 Idem, p. 71. by C. S. Ross, ${ }^{8}$ of the United States Geological Survey. These beds resemble fine-grained light-green sandstone and consist almost exclusively of analcite trapezohedrons that average about 0.06 millimeter in diameter. The individual crystals are surrounded by thin films of glauconitic material. Ross suggests two possible explanations for the origin of the analcite: It may have formed as a result of reaction between the sodium salts concentrated in the playa lake and the hydrous aluminum silicates in the playa muds; or, on the other hand, as glassy volcanic ash is common in those playas and as the analcite beds contain a small quantity of minerals generally associated with ash, the concentrated sodium salts may have reacted with the decomposed ash to form the analcite. Ross's second interpretation of the origin of the analcite in the playas in Arizona agrees exactly with the writer's interpretation of the origin of the analcite beds in the Green River formation.

\section{ANALCITE BEDS OF THE GREEN RIVER FORMATION}

\section{OCCURRENCE OF THE ANALCITE AND APOPHYLIITE}

Lenses or beds of analcite were found at five different levels in the section of the Green River formation in the canyon of White River, in sec. 27, T. $9 \mathrm{~S}$., R. 25 E., Uintah County, Utah. The largest of these lenses is about 40 feet long and 3 feet 3 inches thick at the thickest place and lies about 700 feet above the base of the formation. At about 13, 85, and 130 feet above it there are other thin beds and lenses. About 50 feet below the largest lens there is a thin bed of oil shale that contains short stubby lenses of analcite. Lenses of analcite were also found about 700 feet above the base of the formation in Hells Hole Canyon in sec. 22, T. 10 S., R. 25 E., Uintah County, Utah. Thin sections cut from material collected in Colorado by D. E. Winchester in 1914 showed that several of the beds consist chiefly of analcite. The samples came from localities (1) north of the iron bridge on the old Watson-Rangely wagon road about 2 miles east of the Utah line (probably in sec. 24, T. 1 N., R. 104 W.), Rio Blanco County; (2) in the cliffs on the north side of White River, along the same road but about 5 miles east of the State line (approximately in sec. 9, T. 1 N., R. 103 W.); (3) in the Cathedral Bluffs, in sec. 26, T. 1 N., R. 100 W., Rio Blanco County. The horizons in the Green River formation at which those beds occur are unknown. The writer found lenticular beds of analcite near the top of the formation farther south along the Cathedral Bluffs, in sec. 26, T. 3 S., R. 99 W., Garfield County, Colo.

Recently Mr. Winchester sent to the writer from De Beque, Colo., a sample of the "marker bed" that lies just above the group of rich oil-shale beds known as the Mahogany Ledge and from Grand

\footnotetext{
${ }^{s}$ Ross, C. S., Sedimentary analcite: Am. Mineralngist, vol. 13, pp. 195-197, 1928.
} 


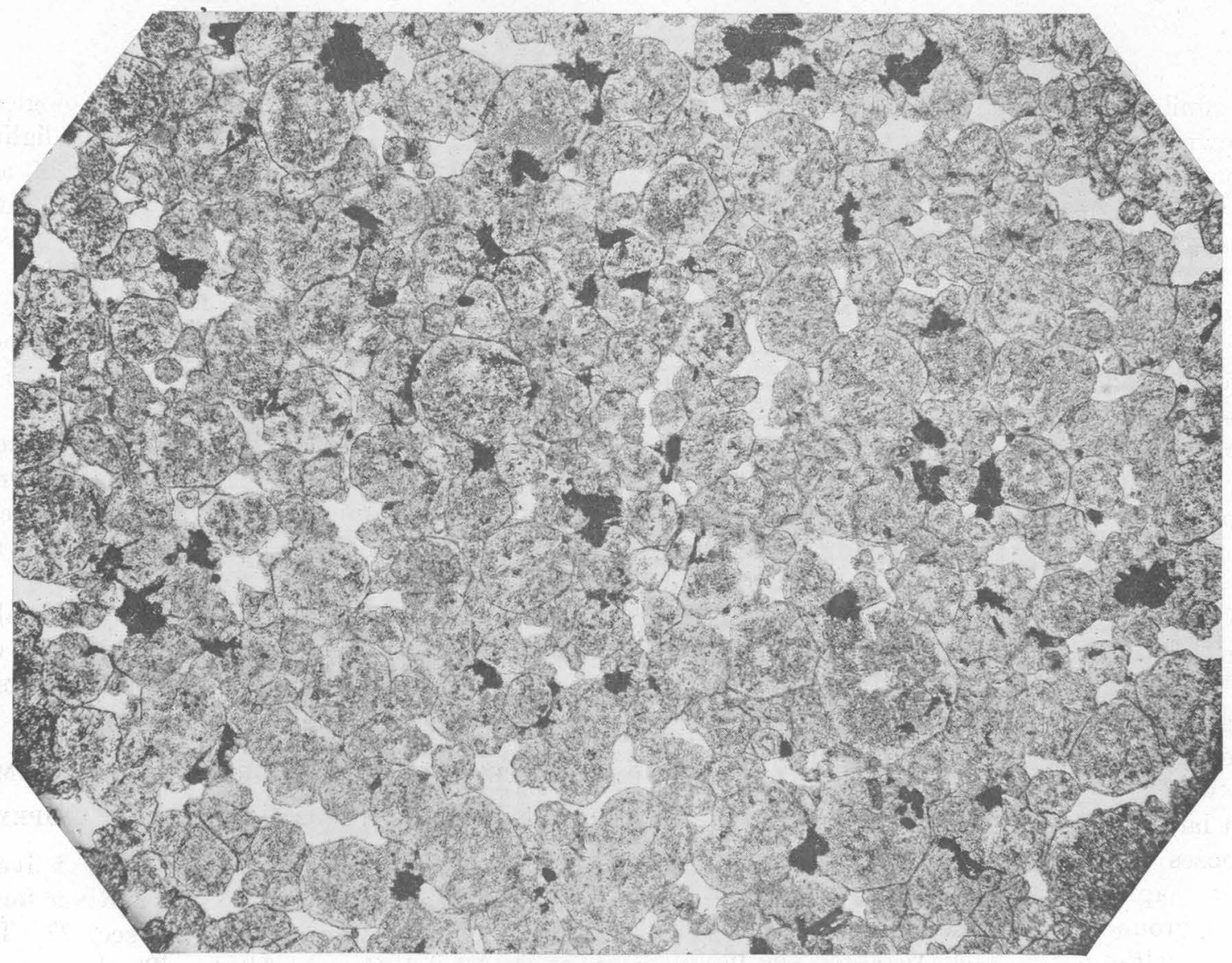

A. PHOTOMICROGRAPH OF A THIN SECTION OF A SPECIMEN FROM AN ANALCITE CRYSTAL BED

Showing the idiomorphism of the crystals and the abundance of dustlike inclusions. The jet-black is pyrite, and the clear gray areas between the crystals are holes in the section. From a bed about 750 feet above the base of the Green River formation in the canyon of White

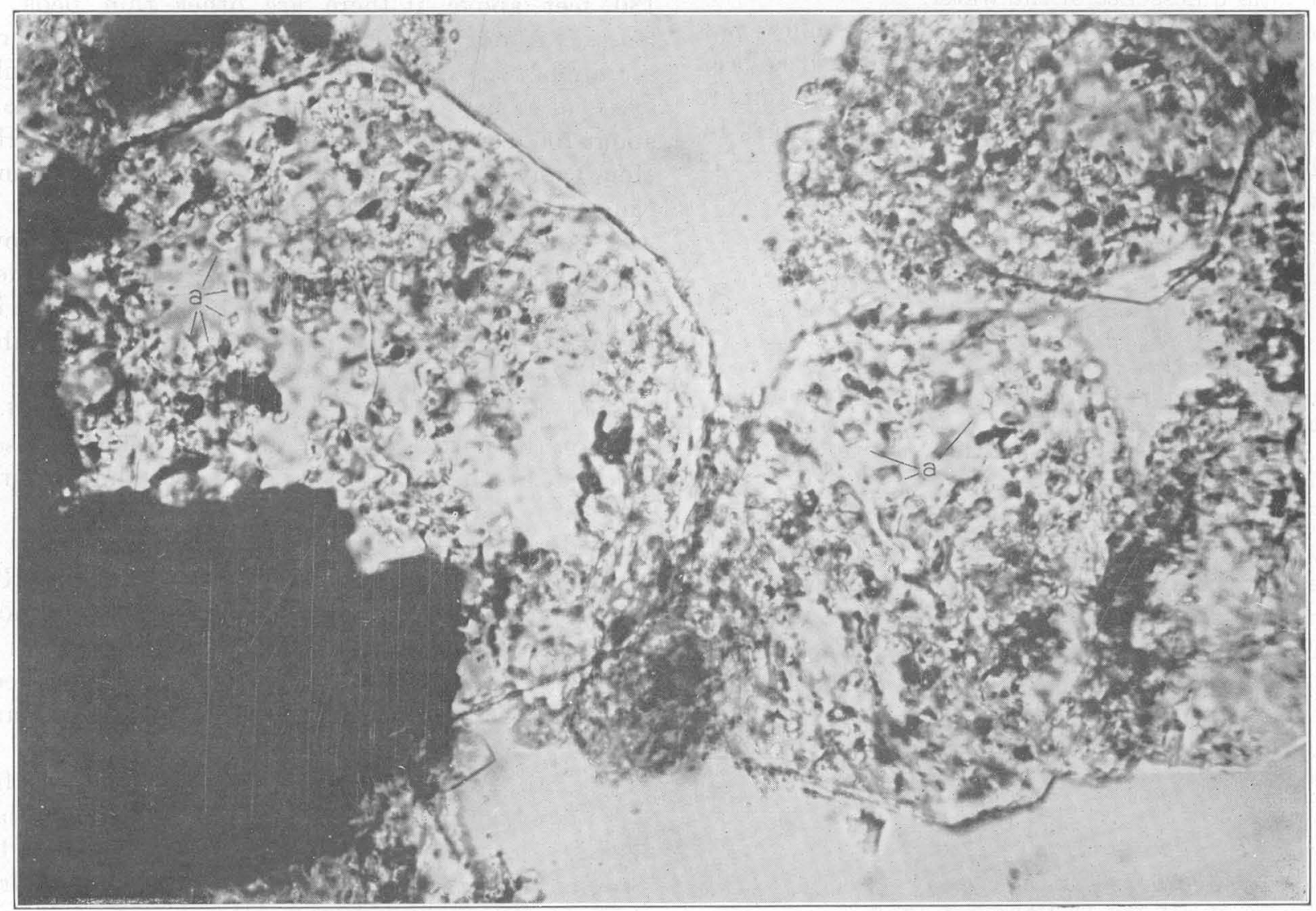

B. PHOTOMICROGRAPH OF A PART OF THE THIN SECTION SHOWN IN $A$

Showing at "a" inclusions of minute lozenge-shaped apophyllite crystals in analcite. Enlarged 500 diameters 


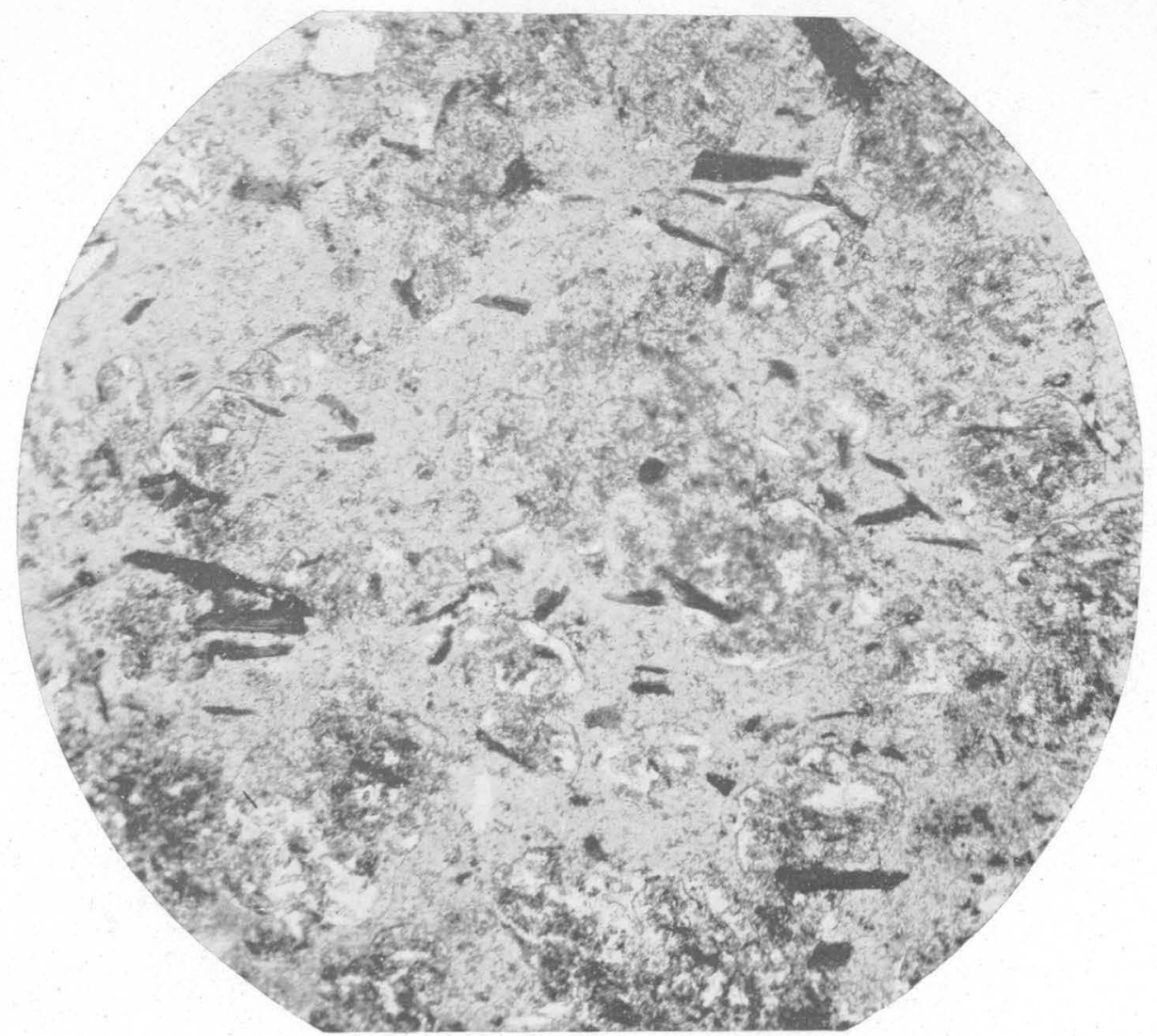

A. PHOTOMICROGRAPH OF A SPECIMEN FROM AN ANALCITE CRYSTAL BED WITH A DISTINCTLY TUFFACEOUS MATRIX

Showing the subparallel orientation of the large biotite flakes, some of which are deeply embedded in the analcite approximately in sec. 9, T. 1 N., R. 103 W., Rio Blanco County, Colo. Enlarged 80 diameters

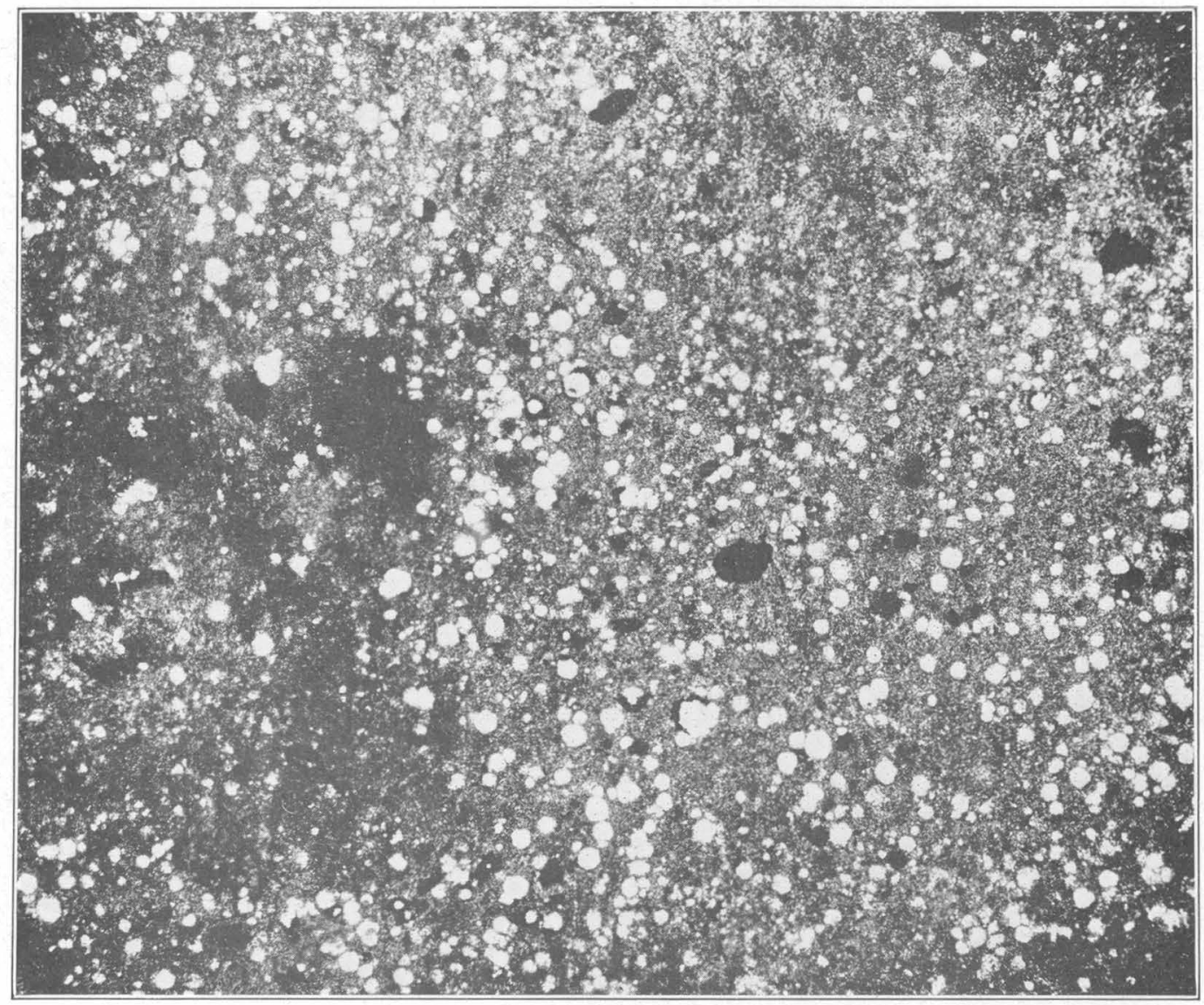

B. PHOTOMICROGRAPH OF A THIN SECTION CUT PARALLEL TO THE BEDDING OF A RICH STRATUM OF OIL SHALE STUDDED WITH ANALCITE CRYSTALS

The finest white specks are grains of dolomite and calcite; the jet-black is pyrite, which in places encircles analcite crystals; and the gray groundmass (almost obscured by the abundance of minute carbonate grains) is structureless organic matter. Enlarged 36 diameters 


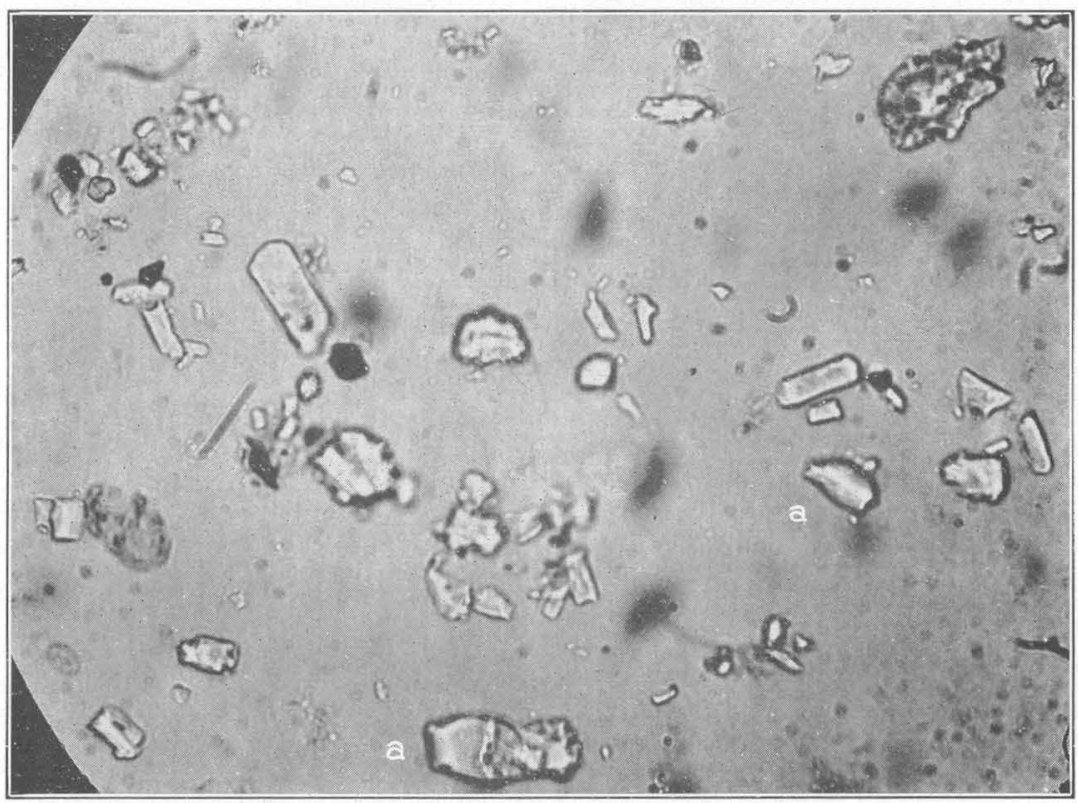

A. PHOTOMICROGRAPH OF A GROUP OF MINUTE APOPHYLLITE CRYSTALS ISOLATED FROM OIL SHALE

Showing nearly perfect prismatic crystals and also irregular forms as at "a." From a thin rich layer of oil shale in the "Mahogany ledge" at the U. S. Bureau of Mines experimental mine in sec. 23,
T. 6 S., R. 96 W. Garfield County, Colo. The grains are immersed in an oil which has a refractive index of 1.58. Enlarged 500 diameters

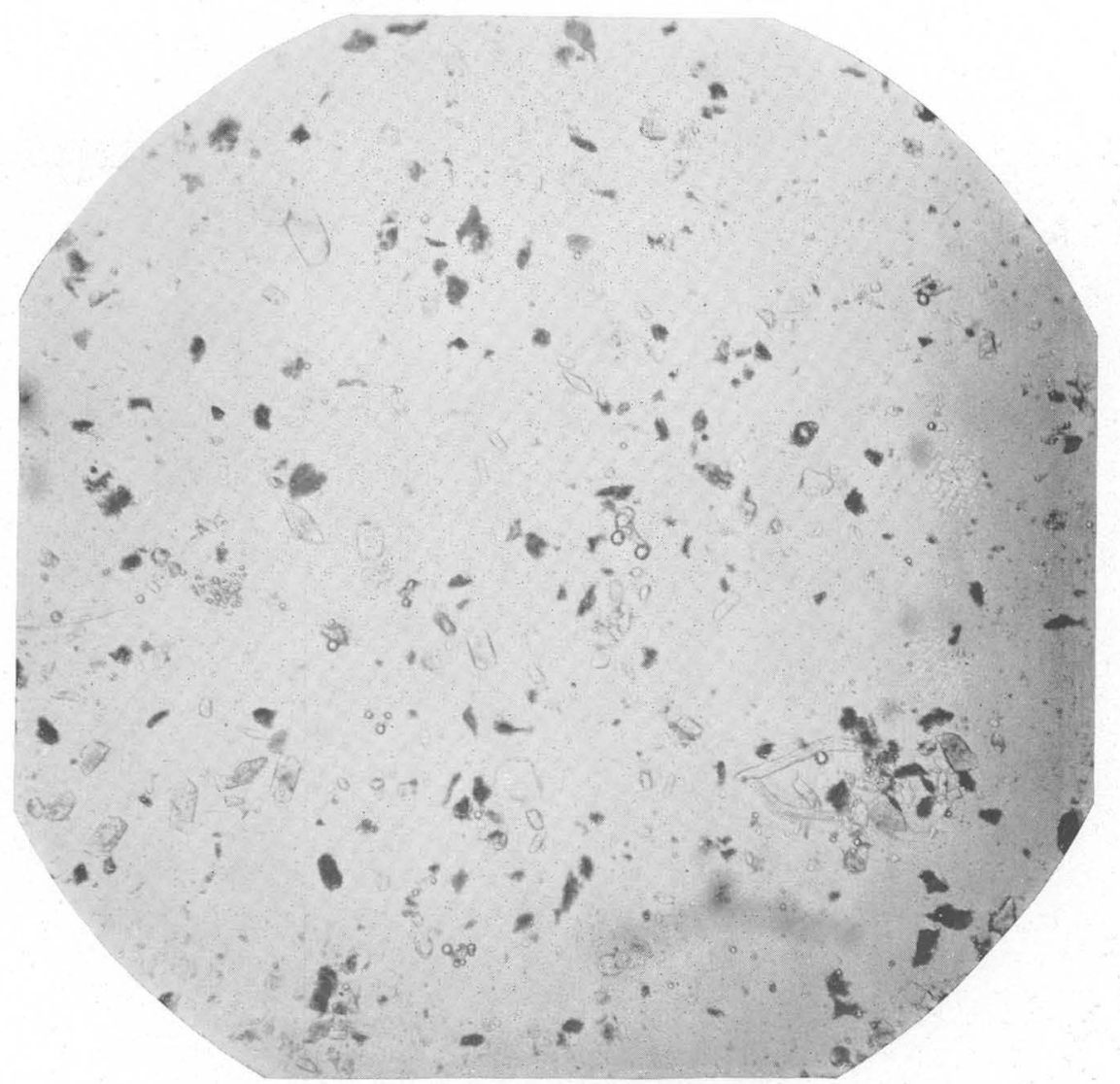

B. PHOTOMICROGRAPH OF A GROUP OF EUHEDRAL SANIDINE AND ORTHOCLASE CRYSTALS ISOLATED FROM OIL SHALE

From a bed in the western part of T. 6 S., R. 95 W., Garfield County, Colo. The grains are immersed in an oil which has a refractive index of 1.58 . Enlarged 80 diameters 
Valley, Colo., a sample of another similar bed that lies about 70 feet below the "marker bed." Thin sections show that both these beds consist of deeply altered volcanic ash contrining an abundance of analcite. Heretofore these "markers" have been regarded either as oolite or as thin beds of sandstone.

The analcite crystals in these beds differ greatly in size, but some are nearly 2 millimeters in diameter. Nearly all are euhedral, though the faces of many are rough and uneven. All are opaque and dull gray. Some are darkly stained with iron oxide.

Thin sections show that the analcite crystals are crowded with minute inclusions, most of which appear to be isotropic, though they may be anisotropic and yet too small to show birefringence. (See pl. 1, A.) In plain light these dustlike inclusions are gray or brownish gray. Fragments of quartz, sanidine, orthoclase, plagioclase, and biotite, together with euhedral crystals of apophyllite, apatite, pyrite, and zircon, are also included in the analcite. Few of the apophyllite crystals so included are more than 0.005 millimeter long. Without exception these tiny crystals are a combination of very short prism and basal plane, which are distorted so that they appear distinctly lozenge shaped in cross section. (See pl. 1, B.) In many analcite crystals the inclusions are grouped in a subparallel manner, and in several of the crystal beds the direction of parallelism is the same not only for the inclusions within the various analcite crystals but also for the oriented grains of the cementing material. The apophyllite crystals do not share in this general orientation, but are oriented at random. In a few analcite crystals there are relatively clear areas whose size and shape are wholly comparable to those of the angular grains of feldspar found as inclusions in analcite crystals of other beds. These clear areas are more or less definitely outlined by the dustlike inclusions and suggest complete replacement of foreign grains, presumably feldspars, by analcite. In fact, some of the very deeply altered orthoclase found as inclusions in analcite crystals may represent a transition step in this replacement.

There appear to have been two stages of analcite formation in at least one of the beds, for the fully grown trapezohedrons of analcite were cracked and the cracks were filled with perfectly clear analcite wholly free from inclusions. These cracks appear to have resulted from the same compression that caused a certain amount of flattening of the crystals during compacting and diagenesis of the beds.

Nearly all the analcite crystals in the crystal beds and also in the oil shale are completely isotropic. Only the borders of the largest crystals and the clear analcite that fills cracks in the older crystals of certain beds show feeble anomalous birefringence. The refractive index is $1.488 \pm 2$.

The matrix of the zeolite beds consists of microcrystalline chalcedony or opal clouded with dustlike inclusions. Embedded in the silica are various quantities of elongate splinters and sharply angular fragments of fresh sanidine and quartz and more or less altered orthoclase and plagioclase, together with a considerable number of laths and plates of biotite. In one bed the biotite is altered to chlorite. Minute euhedral crystals of apatite, apophyllite, and zircon and a few lath-shaped crystals of feldspar terminated by definite faces were also found. Pyrite occurs as aggregates of minute grains and also as tiny cubes and octahedra between the analcite crystals and intergrown with them. Clay minerals and minutely granular carbonates are virtually absent. This lack is noteworthy, as fine carbonate grains and particles of clay minerals predominate in most other beds of the Green River formation.

In one bed of oil shale a little below the Mahogany Ledge at the Monarch Shale Oil Co.'s mine, in sec. 32, T. 6 S., R. 97 W., Garfield County, Colo., analcite makes up a little more than 16 per cent by weight of the rock. (See pl. 2, B.) Another bed of oil shale is worthy of mention because it contains fragments of partly devitrified greenish-brown glass in all stages of replacement by small crystals of analcite. This bed, which occurs in sec. 36, T. 1 N., R. 96 W., Rio Blanco County, Colo., contains also a rather large number of zircon crystals and a little mica.

The trapezohedrons of analcite in the oil-shale beds are considerably smaller than those in the crystal beds. They average about 0.065 millimeter in diameter but range from about 0.004 to 0.15 millimeter. Also, they contain fewer and different inclusions. They are clear and are not clouded with dustlike specks but contain instead minute irregular grains and rhombs of carbonates and tiny flakes of clay minerals. In general, the crystals more than 0.04 millimeter in diameter have been distinctly flattened parallel to the bedding laminae. Vertical sections of some of these show only vague or badly distorted crystal faces, but considered together with their horizontal sections they are clearly trapezohedrons that have been compressed during the compaction of the shale to about half their normal diameter. These distorted crystals contain many irregular cracks, which are not confined to a peripheral zone like the shrinkage cracks of larger analcite crystals.

Apophyllite crystals in the oil shale are neither so large nor so plentiful as the analcite. Most of the crystals are between 0.02 and 0.03 millimeter in length, but many are less than 0.005 millimeter, and none of those measured exceed 0.075 millimeter. The most common form is a rather long first-order prism with second-order pyramid, though many crystals were found which had only one pyramidal termination, the other end being irregularly rounded off. (See pl. 3, A.) Smooth-surfaced fusiform grains that showed no distinct faces were also found; a few of these were more nearly pyriform and resembled Rupert's drops. The 
larger crystals generally contain a few minute inclusions. The writer estimated that apophyllite makes up as much as 5 per cent of a thin streak of exceedingiy rich oil shale from the Mahogany Ledge in sec. 23, $\mathrm{T}$. 6 S., R. 96 W., Garfield County, Colo. In most other oil-shale beds, however, the percentage is considerably smaller.

The apophyllite included in the analcite crystals is either older than the analcite or contemporaneous with it, but the apophyllite not so included may have formed at any time during the history of the Green River formation. There appears to be no way to correlate its growth with that of any other mineral in these beds. On the other hand, there is nothing to suggest two stages of apophyllite formation, and this lack of evidence might perhaps foster the inference that all the apophyllite formed along with the older analcite, very early in the history of the oil shale.

\section{ORIGIN OF THE ZEOLITES}

The hypothesis of a clastic origin for the zeolites does not seem to accord with their observed relations in the Green River formation. Despite the great range in size between the smallest crystals of analcite and apophyllite and the largest crystals of analcite, all occur together without semblance of sorting, and they are accompanied by only insignificant amounts of other clastic grains, such as quartz and feldspar, of comparable size and weight. Moreover, according to the writer's observations, the zeolites in the oil shale seem to be most plentiful in the beds whose clastic constituents, quartz, feldspar, and clay minerals, are markedly subordinate to their chemically precipitated constituents, calcite, dolomite, opal, and pyrite. Then, too, both zeolites appear to be consistently absent from the closely associated beds of fine-grained sandstone and limy siltstone, where they might confidently be expected if they were of clastic origin. Furthermore, many of even the largest analcite crystals have perfectly sharp interfacial angles and show no effects of abrasion. Tor these reasons the idea that these zeolites are a peculiar concentrate derived from disintegration of an-analcite basalt or similar basic rock can je dismissed.

The hypothesis of a hydrothermal origin seems no better suited to explain the occurrence of these zeolites for they are very plentiful in beds of rich oil shale whose organic matter, if given sufficient time, will distill at temperatures as low as $100^{\circ}$ to $200^{\circ} \mathrm{C} .^{9}$ Plainly no such liquefaction has occurred. Furthermore, the oil-shale beds containing the zeolites and also some of the crystal beds extend over hundreds of square miles and occur in two unconnected intermontane basins. The very extent and uniformity of these deposits, coupled with the total absence of any indications of hydrothermal alteration, argue strongly

\footnotetext{
${ }^{9}$ Karrick, L. C., Manual of testing methods for oil shale and shale oil: U. S. Bur. Mines Bull. 249, p. 4, 1926.
}

against the probability of metasomatic action subsequent to the diagenesis of the beds. In fact, the formation of the zeolites within the obviously unaltered oil. shale through the agency of solutions of any kind that entered after lithification of the beds seems inconceivable, because the oil shale is so extremely fine grained and compact that it appears to be utterly impervious to circulating waters. Further than that, during diagenesis both the oil shale and the crystal beds were being progressively compacted, and liquids were being expressed from them. Therefore, solutions from external sources would have had very little opportunity to enter until loading of the beds by younger rocks and the consequent compacting had ceased, but by that time the beds would have reached essentially their present state of imperviousness.

To postulate the action of hot springs as an explanation of such extensive and uniform deposits of zeolites would be to make the patently absurd assumption that not one but both of these ancient lakes, covering in all more than 25,000 square miles, were kept hot for long periods of time. The biologic evidence ${ }^{10}$ alone is sufficient to make this hypothesis untenable.

Hence, it appears that the zeolites in the Green River formation are syngenetic and that they formed at a temperature probably below $30^{\circ} \mathrm{C}$. This interpretation of the origin of analcite and apophyllite departs rather widely from the commonly accepted theory. The writer proposes the hypothesis that these minerals resulted from interaction between the dissolution products of volcanic ash that fell into the ancient Green River lakes and salts dissolved in the lake water. That the zeolites of the crystal beds grew in place seems to be clearly shown by the common orientation of the mineral grains and groups of dustlike inclusions in both the analcite crystals and in the matrix and by the random orientation of the apophyllite crystals, which, being prismatic, might be expected to coincide with the subparallel arrangement of the elongate splinters of quartz, feldspar, and biotite.

In some crystal beds the biotite laths and the elongate splinters of quartz and feldspar in the matrix are oriented roughly parallel to the bedding planes, and this indication of bedding, together with the presence of organic matter diffused through these beds, shows clearly that they accumulated under water. (See pl. 2, A.) Further reason for believing that these zeolites formed on the lake bottom is found in the occurrence of large quantities of both analcite and apophyllite disseminated through many of the oilshale beds, not only in Colorado and Utah but also in Wyoming.

The general distortion of the analcite crystals in oil-shale seems to indicate that they formed when not deeply buried, for the greater part of the compaction of an argillaceous sediment occurs before it has been

10 Bradley, W. H., A contribution to the origin of the Green River formation and its oil shale: Am. Assoc. Petroleum Geologists Bull, vcl. 9, pp. 247-262, 1925. 
buried as much as 100 feet. This inference renders untenable a hypothesis that most of the analcite was formed at the high pressures and high temperatures incident to deep burial, although the clear, obviously secondary analcite that fills cracks may have formed at depth. Probably both the analcite and the apophyllite formed before the organic ooze had-been greatly compacted and had consequently become inimical to the intermingling and reacting of the zeolite constituents.

The intimate relation between the pyrite and the analcite suggests that the analcite formed contemporaneously with or soon after the accumulation of the organic ooze. The pyrite seems plainly to have formed in the organic ooze from an interaction between the iron salts dissolved.in the lake water and hydrogen sulphide derived either from the decay of organic matter or from the reduction of inorganic sulphates as a result of that decay. On this pyrite, much of which has a distinctive, more or less compact microgranular structure, the analcite seems to have exerted a marked localizing influence. Many of the analcite crystals are ringed with aggregates of pyrite granules or with minute cubes and octahedra (see pl. 2, $B$ ), and some appear to be entirely encased in a pyrite shell. Pyrite is also intergrown with analcite. This distribution of pyrite is quite different from that in oil-shale beds that contain little analcite. In them the minute individual pyrite grains or small groups of them are rather uniformly disseminated through the organic matter.

The genetic relation between the zeolites of several of the crystal beds and their tuffaceous matrices is evident. The occurrence of biotite flakes, zircon, and apatite as inclusions in the analcite crystals suggests a volcanic source for the material, but the general aspect, the composition, and the structure of the matrix inclosing the analcite crystals indicate more plainly that these crystal beds resulted from a rather thorough alteration of volcanic ash. Furthermore, the apparent absence from the analcite beds of clay minerals and minutely granular carbonates, which are the predominant constituents of the other beds in the Grcen River formation, strongly suggests that the original material of the zeolite beds accumulated so rapidly that it completely obscured them. Only a fall of ash seems to be consistent with this apparent rapidity of deposition and with the fine grain and mineral composition of the matrix in the analcite beds.

That the zeolites of the oil shale may also be genetically related to the volcanic ash is less apparent but yet seems reasonable. First, there is the analogy between the occurrence of analcite and apophyllite in the crystal beds and their occurrence in the oil shale, beds of the same two minerals bearing the same relations one with the other. Then, the oil shale that contains the zeolites, in common with the tuffaceous crystal beds, contains elongate splinters and sharply angular fragments of sanidine, orthoclase, plagioclase, biotite, and quartz and idiomorphic crystals of sanidine, orthoclase, apatite, zircon, and more rarely also of plagioclase. (See pl. 3, B.) A few zeolite-bearing oil-shale beds contain also fragments of hornblende and altered volcanic glass. The dissemination of the zeolites within an oil-shale bed and the admixture of normal sedimentary minerals, such as the carbonates and clay minerals, seem to be natural consequences if the volcanic ash fell into and became mixed with a nearly fluid organic ooze.

In connection with the alteration of the ash and the formation of the zeolites it is germane to consider the probable chemical character of the lake water into which the ash fell. At many horizons in and above the oil-shale zones of the Green River formation there are abundant salt-crystal molds. W. F. Foshag, ${ }^{11}$ of the United States National Museum, examined some of these molds in a sample collected by the writer from the cliffs just east of the town of Green River, Wyo. He regarded them as probably the molds of glauberite and said:

The simplest form noted is a rhomboid form, corresponding to the combination of prism and the base of glauberite. The interfacial angles are dull and distorted, but an approximate measurement of the prism angle gave $90^{\circ}$. Glauberite has a prism angle of $96^{\circ}$. The agreement is as close as can be expected from this type of material. Another type of crystal mold gives acute and lenticular cross sections corresponding to the type of glauberite crystal in which the prism is prominently developed.

Crystal cavities in rocks of the Green River formation collected later from several other localities were examined for the writer by W. T. Schaller, of the United States Geological Survey. Some of these strongly suggested glauberite and others anhydrite. In a few specimens cavities suggesting both minerals are closely associated. In one specimen from a quarry a short distance northwest of Green River, Wyo., in sec. 15, T. 18 N., R. 107 W., the cavities suggest not only glauberite and anhydrite but a third mineral whose angles do not agree with any known salt. These crystals had a flattened rhomboid form with the following interfacial angles:

$\begin{array}{rr}\mathrm{b}: \mathrm{c}=64^{\circ} & \mathrm{a}: \mathrm{b}=\mathrm{a}: \mathrm{c}=87^{\circ} \\ 65 & 84 \\ 60 & 87 \\ 62 & 86 \\ 65 & 88 \\ 66 & 89 \\ \text { Av. } 64 & \text { Av. } \frac{87}{64}\end{array}$

Probably this mineral is neither new nor unusual but rather a distorted form of a well-known salt.

As the lake water into which the volcanic ash fell contained solutions of these salts it seems reasonable to conclude that the water was more or less alkaline.

Volcanic ash, especially the glassy portions, which are in a metastable condition, must have been quickly attacked by the alkaline lake waters, and thus rela-

1 Personal communication, Jan. 14, 1924. 
tively large quantities of alumina, silica, potash, and other constituents would have been made available for recombination. Many feldspar grains were deeply altered and seem also to have contributed material for recombination. New minerals, stable under the new conditions, could in this manner form contemporaneously over very large areas-indeed, areas coincident with the extent of the lake at the time of each ash fall. Thus the analcite and apophyllite in the Green River formation appear to have formed as reaction products of the silica and alumina liberated by dissolving the volcanic ash with the solutions of sodium, potassium, and calcium salts that were either normal constituents of the lake water or that were also derived from alteration of ash.

\section{CHEMICAL COMPOSITION OF AN ANALCITE BED}

A chemical analysis of a sample from a thin asphaltsaturated ash bed containing much analcite was made in the hope that some information as to the character of the original ash might be obtained. This sample was taken from a bed about 750 feet above the base of the Green River formation in the canyon of White River, in sec. 27, T. 9 S., R. 25 E., Uintah County, Utah. As shown by the analysis given below and the mineral composition computed from it, the ash is too much changed to afford any notion as to its original composition. Apparently much sodium, silica, iron, and water have been added.

Analysis and calculated mineral composition of analcite rock from the Green River formation of Utah

[J. G. Fairchild, analyst]

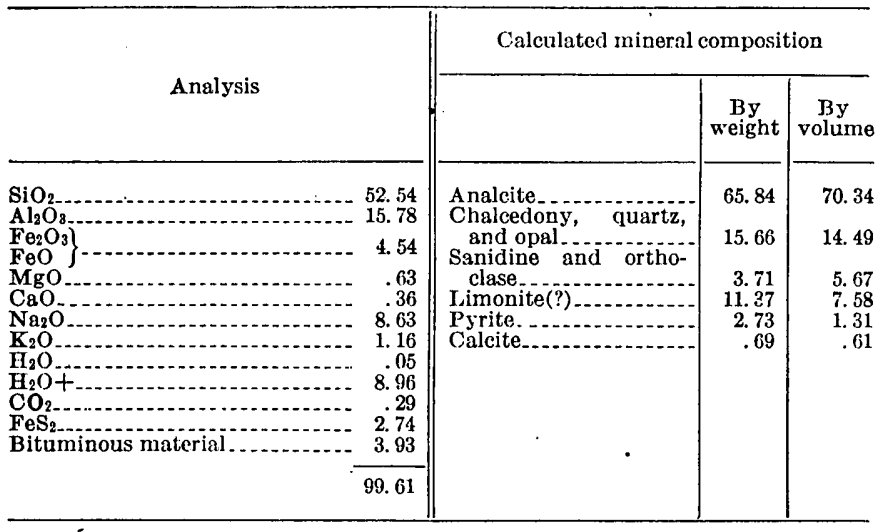

Calculated in this way there is a small excess of $\mathrm{Al}_{2} \mathrm{O}$, and $\mathrm{MgO}$ and several per cent of $\mathrm{H}_{2} \mathrm{O}$. The large amount of limonite is evidently a weathering product of the pyrite, which is very plentiful in the freshest parts of the rocks. Presumably, however, the $\mathrm{MgO}$ and some of the $\mathrm{SiO}_{2}, \mathrm{Al}_{2} \mathrm{O}_{3}$, and $\mathrm{Fe}_{2} \mathrm{O}_{3}$ (or $\mathrm{FeO}$ ) should be combined to make up a part of the dustlike inclusions and tiny fragments of ferromagnesian min- erals. The excess of water is puzzling. A part of it may be contained in opal, and if some of the dustlike inclusions in the analcite are really volcanic glass perhaps they contain a part also.

\section{MEERSCHAUM BEDS OF THE GREEN RIVER FORMATION \\ OCCURRENCE AND COMPOSITION}

Beds of meerschaum, or sepiolite, so far as the writer has been able to learn, have not heretofore been reported from any locality in this country, and it is therefore of interest to record the occurrence of several thin beds, which the writer found in 1925 in the Green River formation. They lie high in the west wall of Indian Canyon, about 4,400 feet above the base of the formation, in sec. 11 (?), T. 10 S., R. 7 W., Duchesne County, Utah. None of the beds of this small group exceed 1 centimeter in thickness. On its weathered surface the material is light bluish gray and has a distinctly silky luster. Below the weathered surface it is dark grayish brown, owing to the large admixture of structureless organic matter. In fact, it is a fairly rich oil shale whose principal inorganic constituent is sepiolite, and like some other oil shales of this formation it has a pronounced fissility and resembles matted coarse brown paper pulp. Unlike other oil shales, however, it is light enough when dry to float on water. The sepiolite layers are interbedded with chocolate-brown oil shale that contains an abundance of glauberite (?). molds that are now partly filled with calcite.

Thin sections show that the sepiolite is all crystalline and that it consists of a felt of excessively fine fibers that have positive elongation. The refractive indices, $\alpha=1.528 \pm 2 ; \gamma, \beta=1.538 \pm 2$, are somewhat higher than those given by Larsen ${ }^{12}$ for $\beta$ sepiolite, namely, $\alpha=1.519, \gamma=1.529, \beta=1.52$, but the birefringence is approximately the same. The mineral is biaxial and negative, with $2 \mathrm{~V}$ fairly large. It does not gelatinize when heated with strong $\mathrm{HCl}$, but, instead, granular silica separates out. Hence, according to Vernadsky's distinction ${ }^{13}$. between two varieties of sepiolite, this appears to be the $\beta$ variety.

The material is mixed with minute crystals and spherulites of calcite and a considerable amount of organic matter, but some of the cleanest fibrous mineral was picked out and analyzed. The results of this analysis and the recalculated form are given below, together with the theoretical composition of sepiolite for comparison.

${ }^{12}$ Larsen, E. S., The microscopic determination of nonopaque minerals: U. S. Geol. Survey Bull. 679, p. 245, 1921.

13 Vernadsky, W., Zur Theorie der Silicate: Zeitschr. Kryst. Min., vol. 34, pp $46-47,1901$. 
Analysis of fibrous sepiolite from the Green River formation of Ul.ah

[E. T. Erickson, anniyst]

\begin{tabular}{|c|c|c|c|}
\hline & $\begin{array}{l}\text { As re- } \\
\text { ported }\end{array}$ & $\begin{array}{l}\text { Recalcu- } \\
\text { lated }\end{array}$ & $\begin{array}{l}\text { Theoret- } \\
\text { ical a }\end{array}$ \\
\hline \multirow[t]{2}{*}{$\begin{array}{l}\mathrm{SiO}_{2} \\
\mathrm{Al}_{2} \mathrm{O}_{\mathrm{O}_{3}} \\
\mathrm{Fe}_{3} \mathrm{O}_{3} \\
\mathrm{Mg}^{1} \mathrm{O}\end{array}$} & $\begin{array}{r}35.92 \\
\text { b. } 10 \\
10.26 \\
1.88 \\
.10 \\
1.14 \\
43.20\end{array}$ & $\begin{array}{r}58.40 \\
1.89 \\
26.42 \\
.69 \\
.10 \\
11.86\end{array}$ & 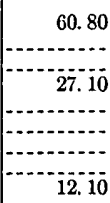 \\
\hline & 100.00 & 100.00 & 100.00 \\
\hline
\end{tabular}

a Dann, J. D., Systom of mineralogy, 6th ed., n. 680, 1909.

- Uncorrectod for $\mathrm{P}_{2} \mathrm{O}_{s}$, if present.

In recalculating this analysis it was assumed that all the $\mathrm{CO}_{2}$ was combined with $\mathrm{CaO}$, for according to the refractive index $(\omega=1.66 \pm 2)$, the calcite is practically pure. This left an excess of 0.69 per cent of $\mathrm{CaO}$ as an impurity. Then, as the water could not be determined because of the organic matter present, an amount of water chemically equivalent to the amount of $\mathrm{MgO}$ was assumed. It should be noted, however, that, wholly apart from these assumptions, the silicamagnesia ratio of the Utah mineral, 2.20 agrees very closely with that of the theoretical sepiolite, 2.24. The other constituents shown by the analysis are probably to be regarded either as impurities of the mineral itself or as admixtures.

\section{COMPARISON WITH EUROPEAN MEERSCHAUM BEDS}

This Utah deposit of sepiolite is comparable to those in the Paris Basin and at Vallecas, about 5 miles south of Madrid, in both of which, according to Brongniart, ${ }^{14}$ the sepiolite occurs in Tertiary lake beds, associated

14 Brongniart, Alex., La magnésite du bassin de Paris: Annales des mines, vol. 7, pp. 303-304, 1822. with gypsum and rock salt and interbedded with marly limestone and limy marl. It is also much like the sepiolite in the fresh-water Tertiary lake beds in southern France near Sommieres, described by De Serres. ${ }^{15}$ It differs from all these, however, in several respects. Silica, usually as some variety of opal, is consistently associated with the European sepiolite beds, but it is apparently absent from the Utah deposit. On the other hand, the Utah sepiolite is intimately associated with a large quantity of organic matter and is accompanied by glauberite (?) and magnesite rather than gypsum or rock salt.

\section{ORIGIN OF THE MEERSCHAUM}

At the time the sepiolite formed, that part of the ancient Green River lake in the vicinity of Indian Canyon, Utah, seems to have been very shallow and saline. Most of the shale beds just below as well as just above the sepiolite horizon contain an abundance of salt molds (glauberite ?) and pseudomorphs. Suncracked bedding planes, too, are plentiful, and the polygonal pattern on several of these is made more conspicuous by the arrangement of the salt pseudomorphs along the cracks. One sepiolite layer rests upon a sun-cracked and salt-studded surface of this kind. Apparently during this phase of the lake the amount of magnesium in solution exceeded the amount of calcium, for several of the bedding planes of the rocks closely associated with the sepiolite layers are studded with small, crudely fusiform crystals of magnesite. A part of this readily available magnesium apparently combined with silica, perhaps as a hydrated gel, to form sepiolite.

15 De Serres, Marcel, Mémoire sur les terraines d'eau douce: Jour. physiquo, vol. 87, pp. 134-135, 1818. 